Article

\title{
The Energy System and the Sharing Economy: Interfaces and Overlaps and What to Learn from Them
}

\author{
Frederik Plewnia ${ }^{1,2}$ \\ 1 Faculty of Business and Economics, Chair of Sustainable Management and Environmental Accounting, \\ Technische Universität (TU) Dresden, 01062 Dresden, Germany; Frederik.plewnia@tu-dresden.de; \\ Tel.: +49-351-463-34313 \\ 2 Boysen TU Dresden Research Training Group, Technische Universität (TU) Dresden, 01062 Dresden, \\ Germany
}

Received: 13 December 2018; Accepted: 19 January 2019; Published: 22 January 2019

\begin{abstract}
The dissemination of decentralized renewable energy generation, storage and smart metering devices has led to the need for new business models and coordination mechanisms in the energy sector. At the same time, the emerging sharing economy focuses on using digital platforms to coordinate value creation on a decentralized level. While sharing concepts have already been applied to specific energy technologies and microgrids, a more general understanding of what the sharing economy means in the context of the energy sector is still missing. This paper aims to bring these two topics together and to analyze their interfaces and overlaps. For this purpose, this paper draws from existent scientific publications, reports, blog posts, and websites as well as company workshops to discuss which activities and characteristics of the sharing economy might be applicable to the energy sector. Results show that there are significant overlaps in characteristics of the sharing economy and of the transitioning energy system. Furthermore, a broad range of business models within the energy system were found to be based on sharing resources. The findings of this study open up a range of new research and business opportunities at the interface of the sharing economy and the transitioning energy system.
\end{abstract}

Keywords: energy transition; renewable energy systems; sharing economy; prosumer

\section{Introduction}

Uber and Airbnb are two companies that have disrupted the mobility and hospitality sector, respectively, by using digital technologies, employing new market coordination mechanisms and capitalizing on products and services facilitated by individuals in a decentralized manner instead of by the firm itself [1]. Together with companies that offer carsharing, tool sharing, skill sharing, or crowdfunding platforms, these organizations are considered as part of the sharing economy [2,3]. At the same time, capacities of distributed renewable energy generation and storage facilities are increasing and result in the need for new business models and coordination mechanisms in the energy sector. In the context of these two distinct but possibly synergetic developments, various researchers and practitioners have started to transfer principles and ideas of the sharing economy to the energy sector [4-6].

In this context, researchers have drawn on ideas of the sharing economy for a more profitable and efficient use of demand-side energy technologies such as energy storages [7-9]. Others have focused on developing market designs where prosumers (i.e., a producer and consumer of electricity) may share their energy and resources peer-to-peer (P2P) in energy communities or micro-grids [10-12]. Furthermore, sharing energy has been regarded as a possible business model where prosumer needs 
and behavioral aspects should be considered, regulatory barriers need to be overcome, and the energy transition can be driven forward [6,13-15]. While these important research advancements focus on specific technologies, particular business models or possible market systems for prosumers, a more general understanding of what the sharing economy means in the context of the energy sector is still missing. Specifically, this means understanding electricity as a very complex good where P2P sharing might not be easily implemented or poses different challenges compared to shared cars, rooms or digital content. On the other hand, sharing huge power plants has always been part of the electricity system and is hardly anything new. To shed more light on how the sharing economy and the transitioning energy system might interact, the purpose of this paper is to carve out what the general interfaces and overlaps between these two topics are. Accordingly, this paper uses a profound understanding of the sharing economy as a foundation to discuss how business models and characteristics of the sharing economy can be applied in the context of energy. Without claiming to be comprehensive, it draws on scientific as well as grey literature, including articles, blog posts and websites, to assess the current state of research and practice in this area. Furthermore, workshops with companies from the energy sector that have already adapted aspects of the sharing economy in their business model are conducted to gain qualitative empirical insights on this issue.

Findings of this paper show that there is a wide range of businesses active along the interface of the sharing economy and the energy sector. A systematization of the sharing economy was used to structure these new business models along three dimensions of sharing activities, namely the shared good, the market orientation and the market structure. This systematization can help practitioners to position, adapt and extend their organization's business model along these dimensions. Furthermore, joint characteristics of the sharing economy and a transitioning sustainable energy system, such as the relevance of platform organizations, leverage on digital technologies and increased potential for consumer-to-consumer interaction, allowing both fields to learn from one another and open new pathways for researchers emanating from the separate domains.

The paper is structured as follows. Section 2 provides the theoretical background on what the sharing economy is. It may appear out of scope for readers of this journal, but it provides the necessary comprehensive introduction this new topic calls for when hoping to understand the extent to which it can be applied in the energy sector. Section 3 describes how a broad range of online materials and empirical company workshops were used to identify and analyze possible applications of sharing economy concepts in the energy sector. Section 4 then presents the results of this study and discusses what scholars and practitioners in the field of energy may learn from it. Section 5 gives a brief conclusion of this paper.

\section{Theoretical Foundation-What Is the Sharing Economy?}

This section draws on existent literature to lay out what the sharing economy is. First, it describes what different meanings of the term "sharing" exist in the context of the sharing economy. Second, it enumerates defining characteristics of the sharing economy and, third, it gives an overview of how activities and business models of the sharing economy might be structured and systemized.

\subsection{Different Meanings of the Term "Sharing"}

To understand some of the issues involved when trying to define the sharing economy, it is useful to take a step back and consider what the term "sharing" actually means. Traditionally, "sharing something" was either done in the inner circle of a family, friends, or a village and was based on strong social ties, or it was done with others to establish social bonds, e.g., a household sharing food and shelter with a guest $[16,17]$. This form of social sharing, accomplished through joint ownership and community acts of giving and receiving, is considered as 'true sharing' and, according to some scholars, should be at the core of the sharing economy [18,19].

However, along with the social relationship that is the base or the result of social sharing, there are also economic advantages of sharing within a group $[16,20]$. As a consequence, goods can be shared, 
instead of owned and used only individually, to make full use of their capacities [21]. Accordingly, economic sharing of a good, as in sharing a taxi or an apartment, can save costs and resources and is another valid use of the term sharing [22].

Besides the socio-economic perspectives of sharing as an act of distribution, sharing can also be used in the context of communication $[23,24]$. People share their feelings with loved ones, share knowledge within their community and share ideas and information with colleagues. Although this form of communicational sharing of knowledge and information is closely related to sharing and distributing a good, the important difference is that sharing information is not a zero-sum game, as knowledge multiplies when shared [25]. This means that if knowledge is shared or given from one actor to the other, both actors now possess this knowledge; in other words, the sum of what is given and what is received does not equal zero as with other goods.

All these three meanings of sharing have changed considerably due to the internet and digital technologies. It is now possible to extend acts of sharing to online communities and people all around the globe [26]. While in some cases social relationships may be established and online or offline communities are built via the internet, in other cases, they are not and sharing goods and information is motivated and understood on a purely economic basis. Furthermore, another dimension of sharing is added by the occurrence of digital content sharing, which enables people to multiply and disseminate videos, music, information, and knowledge at almost no cost [25,27].

Another important aspect which contributes to the understanding of the term sharing is the definition Benkler [21] provides for 'shareable goods'. According to his explanations, shareable goods need to be lumpy and mid-grained. Lumpy means that the goods come in a certain capacity which is not completely identical with the individual demand and, thus, create excess capacity. Mid-grained means that goods are affordable and well distributed among the people of a society. In contrast to mid-grained goods, large-grained goods are too expensive for individuals, or even have locally shared ownership and are owned by large companies or the state, which provide services based on these large-grained goods (e.g., power plants or infrastructure) [21]. Consequently, these types of goods are excluded from the analysis within this article. While cars and computers, examples to which Benkler [21] refers in his article, have been mid-grained for some time now, energy generation and storage technologies are only now becoming mid-grained and, thus, are currently opening as a field for new sharing possibilities. "If enough individuals in society buy and use such mid-grained lumpy goods, that society will have a large amount of excess capacity 'out there', in the hands of individuals" [21].

\subsection{Definitions and Characteristics of the Sharing Economy}

In addition to discussions on which the form of sharing is at the core of the sharing economy, the novelty and dynamic of the phenomenon, and simultaneous efforts of research, press, and industry to describe what the sharing economy is and who is part of it, have resulted in a range of differing and partly conflicting definitions $[18,19,22]$. Meanwhile, research has attempted to synthesize and make sense of this somewhat ambiguous concept [22,28-31]. As a synthesis of the status quo of sharing economy definitions, Table 1 summarizes some of the most recent contributions.

However, as these definitions still struggle to balance being too broad, i.e., including too many activities and being too narrow, i.e., leaving out too many activities that are considered sharing by others, some scholars have moved on to mapping the sharing economy by systemizing it and seeking out its core characteristics [28,30-32]. Accordingly, instead of focusing on one clear cut definition of what the sharing economy is or is not, this paper builds on defining characteristics or attributes of the sharing economy to see how these can be transferred to the energy sector. To gather the most common characteristics of the sharing economy, these were collected from publications which had compiled and synthesized these characteristics from a multitude of different sources themselves [22,28,31,33]. As a result, Table 2 represents a list of the most frequently indicated sharing economy characteristics. 
Table 1. Illustrative definitions of the sharing economy.

\begin{tabular}{cl}
\hline \multicolumn{1}{c}{ Publication } & \multicolumn{1}{c}{ Definitions } \\
\hline Codagnone et al., 2016 [29] & $\begin{array}{l}\text { "the expression sharing economy is commonly used to indicate a wide } \\
\text { range of digital commercial or non-profit platforms facilitating } \\
\text { exchanges amongst a variety of players through a variety of interaction } \\
\text { modalities (P2P, P2B, B2P, B2B, G2G) }{ }^{1} \text { that all broadly enable } \\
\text { consumption or productive activities leveraging capital assets (money, } \\
\text { real estate property, equipment, cars, etc.) goods, skills, or just time". }\end{array}$ \\
\hline Frenken \& Schor, 2017 [22] & $\begin{array}{l}\text { "Consumers granting each other temporary access to under-utilized } \\
\text { physical assets ("idle capacity"), possibly for money." }\end{array}$ \\
\hline Munoz and Cohen, 2017 [31] & $\begin{array}{l}\text { "A socio-economic system enabling an intermediated set of exchanges of } \\
\text { goods and services between individuals and organizations which aim to } \\
\text { increase efficiency and optimization of sub-utilized resources in society" }\end{array}$ \\
\hline $\begin{array}{l}\text { 1 P2P = peer-to-peer, P2B = peer-to-business, B2P = business-to-peer, B2B = business-to-business and G2G = } \\
\text { government-to-government are possible interaction modalities in the sharing economy and refer to the actors } \\
\text { involved in a sharing economy transaction, where 'peer' is used as a synonym for consumer. }\end{array}$
\end{tabular}

Table 2. Key aspects of the sharing economy.

\begin{tabular}{|c|c|c|}
\hline Aspect & Description & Sources \\
\hline Platform-based & $\begin{array}{l}\text { Business relies on a digital or } \\
\text { physical platform for collaboration }\end{array}$ & $\begin{array}{l}\text { Acquier et al., } 2017 \text { [28]; } \\
\text { Frenken and Schor, } 2017 \text { [22]; } \\
\text { Munoz and Cohen, } 2017 \text { [31]; } \\
\text { Botsman, } 2015 \text { [33]. }\end{array}$ \\
\hline $\begin{array}{l}\text { Leverage on digital technologies } \\
\text { to enable sharing with strangers }\end{array}$ & $\begin{array}{l}\text { Business leverages or relies on } \\
\text { technology to operate. }\end{array}$ & $\begin{array}{l}\text { Acquier et al., } 2017 \text { [28]; } \\
\text { Frenken and Schor, } 2017 \text { [22]; } \\
\text { Munoz and Cohen, } 2017 \text { [31]. }\end{array}$ \\
\hline $\begin{array}{l}\text { Consumer-to-consumer/ } \\
\text { peer-to-peer interaction }\end{array}$ & $\begin{array}{l}\text { Business model enables and/or } \\
\text { relies on peer-to-peer interactions } \\
\text { and transactions. }\end{array}$ & $\begin{array}{l}\text { Acquier et al., } 2017 \text { [28]; } \\
\text { Frenken and Schor, } 2017 \text { [22]; } \\
\text { Munoz and Cohen, } 2017 \text { [31]. }\end{array}$ \\
\hline Access instead of ownership & $\begin{array}{l}\text { Business enables short term access } \\
\text { to assets (material resources or } \\
\text { skills) to optimize their use. }\end{array}$ & $\begin{array}{l}\text { Acquier et al., } 2017 \text { [28]; } \\
\text { Frenken and Schor, } 2017 \text { [22]; } \\
\text { Botsman, } 2015 \text { [33]. }\end{array}$ \\
\hline $\begin{array}{l}\text { Under-utilized resources/making } \\
\text { better use of idle capacities }\end{array}$ & $\begin{array}{l}\text { Resources are shared by users and } \\
\text { the business relies on excess } \\
\text { capacity of resources. }\end{array}$ & $\begin{array}{l}\text { Acquier et al., } 2017 \text { [28]; } \\
\text { Frenken and Schor, } 2017 \text { [22]; } \\
\text { Munoz and Cohen, } 2017 \text { [31]; } \\
\text { Botsman, } 2015 \text { [33]. }\end{array}$ \\
\hline Shared values/mission driven & $\begin{array}{l}\text { Ecological and social logics are } \\
\text { driving community based } \\
\text { business models. }\end{array}$ & $\begin{array}{l}\text { Acquier et al., } 2017 \text { [28]; } \\
\text { Munoz and Cohen, } 2017 \text { [31]; } \\
\text { Botsman, } 2015 \text { [33]. }\end{array}$ \\
\hline
\end{tabular}

Although some of these aspects are at the core of the sharing economy, not all of them have to be existent for a given company to be part of the sharing economy [31]. Nevertheless, the more attributes which are integrated in their business model, the more likely organizations might be considered as such. After all, sharing economy companies are not all the same and have different specifics in their business model $[28,31]$.

\subsection{Types of Business Models of the Sharing Economy}

Following the line of thought that the sharing economy is not one homogenous phenomenon but an overarching concept with diverse business models, Plewnia and Guenther [32] proposed a typology for different sharing economy activities. This typology distinguishes four dimensions, namely the shared good, the market orientation, the market structure, and the industry sector the sharing activity takes place in. The shared good dimension asks the question of what is being shared and 
differentiates along a spectrum of tangible towards intangible goods between material (recovery and recycling), products (redistribution markets), product service systems (PSS), space, money, workforce (time and skills), knowledge, and education, as well as data and information. The market orientation distinguishes sharing platforms that are based on for-profit (i.e., a fee is paid for a service) or non-profit (i.e., service or good is distributed for free) transactions between actors but can also assess if a business model is oriented towards global or local markets or based on online or offline platforms. The market structure of a sharing business model can be business-to-consumer (B2C), as in conventional carsharing; consumer-to-consumer (C2C), as in Airbnb or Uber; consumer-to-business (C2B), as in in crowdfunding or crowdsourcing platforms; business-to-business (B2B), as in industry networks; or government-to-consumer (G2C), as in city bike sharing schemes. The last dimension addresses the industry sector the sharing business model has been established in, which might be the mobility, hospitality, entertainment, or, as is the focus of this paper, energy sector.

All these theoretical approaches have been developed to map out and conceptualize the sharing economy in general. Based on these theoretic approaches, the goal of this paper is to analyze how concepts of the sharing economy are or can be transferred to the energy sector, especially in the light of transitions towards a more sustainable, renewable and distributed energy system.

\section{Methods}

To enhance the conceptual understanding of how the sharing economy can be applied in the energy sector, three major steps are taken. First, literature on the sharing economy in general was analyzed to gain a profound understanding of the phenomenon labelled the 'sharing economy'. Findings of this preparatory work were summarized in the previous section.

As a second step, new business models, activities or companies within the energy sector which were associated with the sharing economy or related terms were searched for. To find publications or documents which referenced ideas of the sharing economy in the context of the energy sector, an explorative search was conducted in scientific and other databases. Keywords, such as "energy system", "prosumer", "demand side management", or "electricity grid" were used in combination with the terms "sharing economy", "collaborative economy", "peer economy", "Uber", or "Airbnb". Based on initial results, documents containing the terms "peer energy", "cloud energy", or "energy sharing" were also searched for. Furthermore, sources, projects and companies which were cited within the found documents were added to the analysis. Consequently, results included in the analysis were not restricted to scientific articles but also contained conference proceedings, presentations, reports, news articles, blog posts, as well as company and project websites. In total, the content of 70 sources was analyzed for intersections between new business models in the energy sector and the sharing economy. However, this paper does not claim to provide a comprehensive systematic overview of all work done on the interface of the sharing economy and the energy sector. Rather, it takes a more conceptual approach towards combining the two topics. Accordingly, the documents found were used to analyze, following the typology of Plewnia and Guenther [32], which types of sharing economy business models are already applied in the energy sector and which might be explored in the future.

Based on the results of step 1 and 2, company workshops were conducted to discuss how aspects of the sharing economy may be applied in the energy sector and which sharing business models might be viable in the energy sector in the future. For this purpose, five companies within the energy sector, which had already implemented aspects of the sharing economy into their business model and were roughly familiar with the phenomenon, were selected. These companies were all based and mainly operating in the energy market of a developed country where the transition towards renewable energies had already advanced significantly and business models were currently changing, namely in Germany [34-36]. Within the workshops, the companies were asked about their understanding of the sharing economy, they were made familiar with the conceptual understandings within the literature presented in Section 2, and were asked how this might apply to their business model. Furthermore, they were asked to arrange their firm activities with respect to sharing in the typology presented in 
Section 2.3. Finally, it was discussed whether they could imagine future sharing activities for their company based on the workshop results. Workshops were held with each of the five companies individually, giving a total of five workshops overall. The number of workshop participants ranged from one to five persons and the duration of the workshops was between 63 and $107 \mathrm{~min}$. All names of workshop participants and their statements were anonymized for the evaluation of the workshops. A short overview of workshop participants is presented in Table 3. The steps taken during the research process and associated results are illustrated in Figure 1.

Table 3. Overview of conducted company workshops.

\begin{tabular}{|c|c|c|c|c|}
\hline $\begin{array}{l}\text { Company } \\
\text { Participating in } \\
\text { the Workshop }\end{array}$ & Company Field of Activity & $\begin{array}{l}\text { Company } \\
\text { Employees }\end{array}$ & $\begin{array}{c}\text { Workshop } \\
\text { Participants }\end{array}$ & $\begin{array}{c}\text { Workshop } \\
\text { Duration }\end{array}$ \\
\hline$\# 1$ & $\begin{array}{l}\text { Municipal utility providing a } \\
\text { peer-to-peer electricity platform }\end{array}$ & $>250$ & 4 & $107 \mathrm{~min}$ \\
\hline$\# 2$ & Digital electricity provider & $<50$ & 5 & $85 \mathrm{~min}$ \\
\hline$\# 3$ & Green electricity provider & $<50$ & 1 & $89 \mathrm{~min}$ \\
\hline$\# 4$ & $\begin{array}{c}\text { Producer of home energy } \\
\text { storage systems }\end{array}$ & $>250$ & 1 & $85 \mathrm{~min}$ \\
\hline$\# 5$ & $\begin{array}{l}\text { Peer-to-peer electricity platform } \\
\text { for green and local energy }\end{array}$ & $<50$ & 1 & $63 \mathrm{~min}$ \\
\hline
\end{tabular}

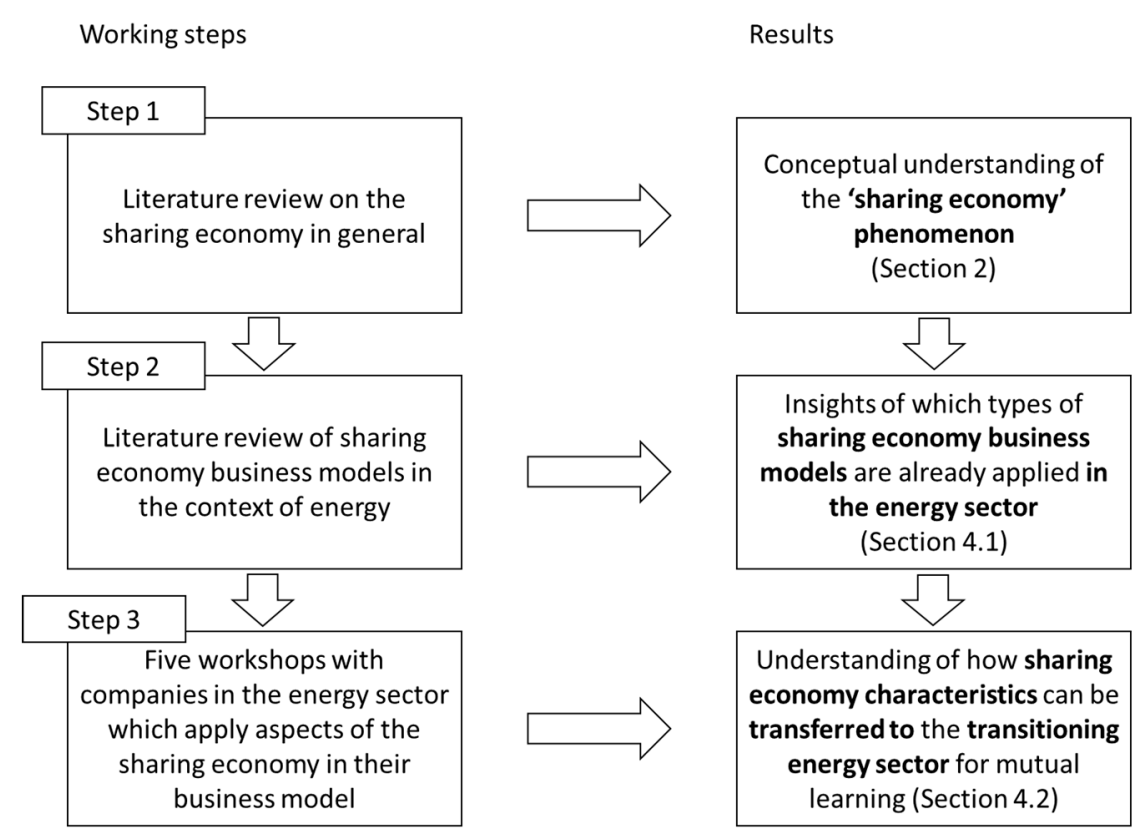

Figure 1. Steps of research process and associated results (own illustration).

\section{Results}

The results of this paper discuss how ideas and principles of the sharing economy can be transferred to the energy sector in two ways. First, existent and possible business models on the interface of the sharing economy and the energy sector, which were gathered through the literature analysis and company workshops (steps 2 and 3, Figure 1), are described along the typology of sharing activities by Plewnia \& Guenther [32]. Based on this overview and the insights from the company workshops, it is examined how characteristics of the sharing economy may also apply to the transitioning energy system and what we can learn from them. 


\subsection{Sharing Economy Business Models in the Energy Sector}

As explained in Section 2.3, the sharing economy can be roughly systemized along four dimensions: the shared good, the market orientation, the market structure, and the industry sector. With respect to the industry sector, other studies that discussed the sharing economy in general have focused more on the sectors hospitality, mobility or consumer goods [37-39]. However, this paper seeks to discover the intersections of the sharing economy and new business models in the energy sector and, accordingly, only considers the latter. However, with respect to the other dimensions, business models associated with sharing were found to be discussed in almost all categories of the typology (compare Figure 2). In the following, each category of the dimension of shared good will be reviewed in a separate subsection, where the dimensions market orientation and market structure are also addressed within each of these subsections.

\subsubsection{Material and Energy}

This category, which was originally labelled 'material (recovery and recycling)', was complemented with 'energy' as the good energy seemed most fitting to this category as it considers raw input materials and how these can be shared or redistributed for optimal usage. Although the tangibility of energy is debatable, it can be considered a very tangible good when considering its basic physical attributes. Furthermore, it is an input variable in many production processes and it can also be recycled or recovered along the process (i.e., in the form of heat). For this reason, it was attributed to the category 'material' within the systematization used within this paper.

With the technological development of decentralized energy system components, electric energy generation and storage devices are currently becoming more and more cost efficient and affordable for small actors. As lumpy and mid-grained goods are increasingly distributed among businesses and private households (compare Section 2.1), energy technologies come with certain capacities. These capacities do not always match the demand of the individual owner and, thus, provide excess capacity which can be traded or shared on secondary markets [21]. New developments in the energy sector take account of these developments and offer business models meant to utilize these excess capacities.

The concept which is most discussed in this context is P2P or C2C energy sharing or trading $[10,12,40]$. Platforms, provided by companies like Beegy, Buzzn, Vandebron, Sonnen, or Piclo, offer their customers the possibility to 'share' their excess energy with other community members or with buyers [41]. However, it must be pointed out that, as long as financial transactions are involved, it is rather the PV or wind production facility that is shared economically instead of the energy itself, which is sold and consumed as in traditional energy contracts (\#4, \#5). Additionally, due to the complexity of the physical electricity grid, most P2P platforms and sharing energy communities enable forms of virtual energy sharing and trading, where electricity is 'shared' on a balance sheet but not physically (\#4). In microgrids, on the other hand, the financial trading might correspond with the actual physical flows of electricity.

These concepts might even gain more attraction due to blockchain technology, which drives down the transaction costs and reduces the necessity of intermediaries. This might enable new forms of energy sharing communities based on microgrids and virtual power plants, where sharing energy within the microgrid is the most feasible option economically [11,42-44]. For the moment, it remains unclear and might be an interesting realm for future research how these developments of blockchain-coordinated microgrids and further reduction of technology costs will take the energy system more in the direction of a 'true' sharing economy, where surplus energy is distributed at costs close to zero [27]. 


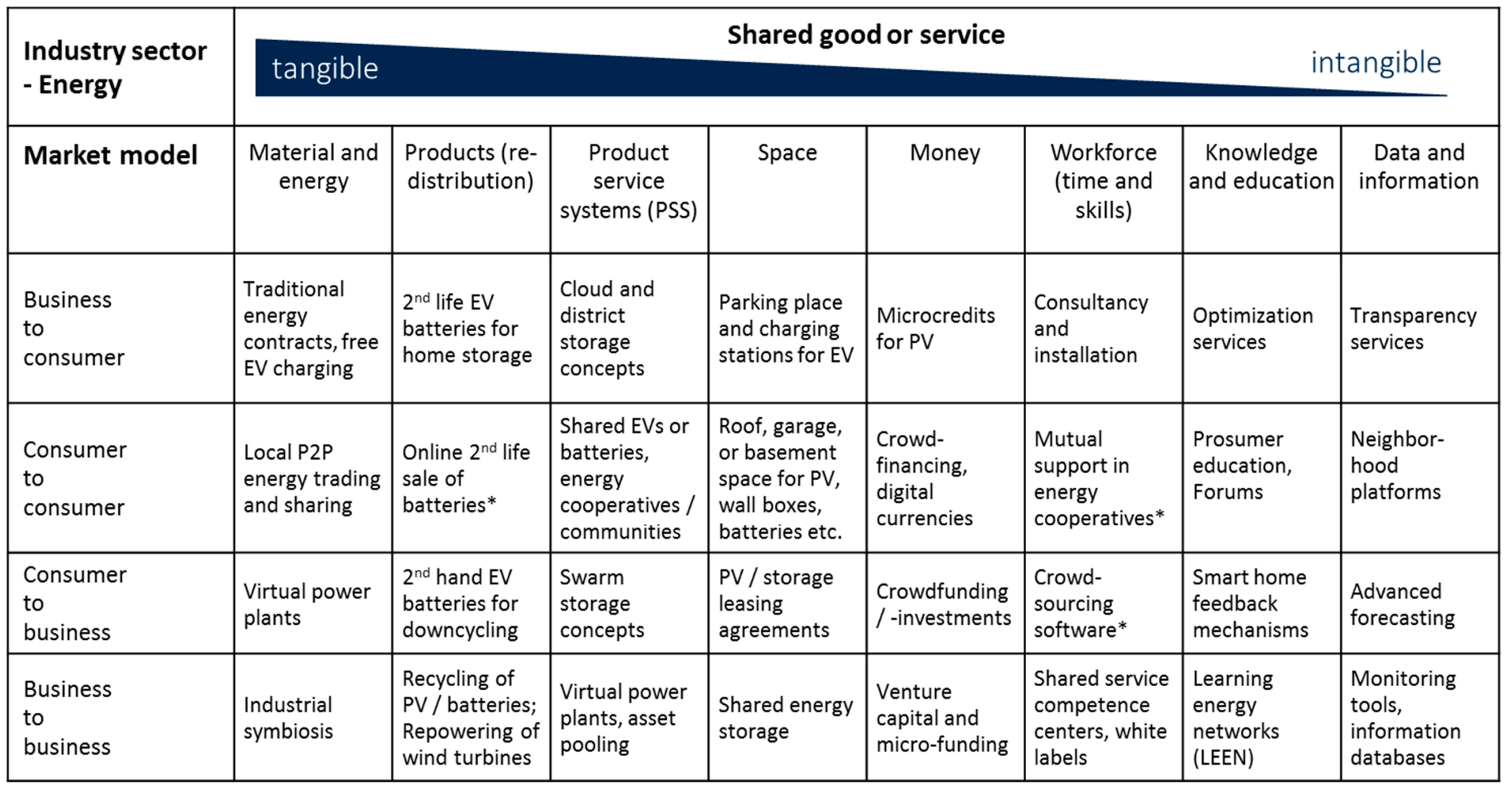

Figure 2. Overview of sharing activities in the energy sector (adapted from Reference [32]). EV = electric vehicles; P2P = peer-to-peer; PV = photovoltaic. Business models indicated with an asterisk $\left({ }^{*}\right)$ are still at the idea stage and no specific implementation of this sharing activity was found. 
On a B2C basis, true sharing already occurs when companies are provisioning their customers or employees with free energy at electric vehicle (EV) charging stations [45]. Furthermore, the shared use of resources among businesses (B2B) has been discussed for a long time under the buzzword 'industrial symbiosis'. This concept might be based on for-profit or non-profit sharing and is gaining new attention with the expansion of digitalization and the internet of things [46,47]. Although industrial symbiosis is not really discussed in the context of the sharing economy as of yet, connecting these two research domains might offer important new insights for experts of both fields.

\subsubsection{Products (Redistribution)}

Online redistribution markets in the context of energy technologies were not found within the research scope of this paper. The reuse of EV batteries for home storage is viable and an environmentally beneficial business model [48,49]. However, no relation to the sharing economy has been found so far. The reuse of electric vehicle batteries and of other energy generation or storage technologies is only possibly as a B2C or B2B business model because the disassembly and technical adaption is carried out by specialized companies. A C2C business model has not been found and is probably difficult to realize with the current state of technology, although it might be an option for the future. At the same time, the necessity of centralized and specialized disassembly companies makes a local sharing character within communities difficult. For now, these business models are more associated with a circular economy than a sharing economy. However, in other cases, there might be overlaps between the two latter concepts, especially within the categories material and energy, products, and PSS.

\subsubsection{Product Service Systems (PSS)}

To discuss goods in the energy system that are possibly shared based on PSS, three different types of PSS can be considered: long-term leasing, short-term renting, and result-based PSS. First, long-term leasing contracts are a form of PSS which can significantly contribute to the transformation of the energy system but are not really a form of sharing [15]. Although this business model follows the principle of 'access instead of ownership', the leasing contract usually covers most of the whole life cycle of the product. Thus, this concept is obviously more comparable to car leasing than to carsharing and costs or benefits of the product are not really shared with anyone. This form of long-term PSS, however, might become a shared good if the excess capacity and the energy generated with this capacity is shared within P2P networks as described earlier.

Short-term rental of goods, on the other hand, can be considered as sharing because products are sequentially used by a large number of users which share the costs and benefits of this good. Examples for short-term rental in the energy sector are EV carsharing, powerbank rental (e.g., Ampero) or EV battery exchange systems. Because goods are shared on an economic basis within most business models, this is another form of economic instead of social sharing.

Finally, result-based PSS offers a service without having to own a product even for a short period of time. Business models proposed by Liu et al. [7] or Lombardi \& Schwabe [8] offer these kinds of services for energy storage systems on a B2C or B2B level. District storage systems can provide a similar local form of sharing an asset (\#3). However, when the storage is centrally owned, installed and managed, this more or less resembles a conventional electricity system and is not the mid-grained form of sharing as described by Benkler [21]. On the other hand, when cloud storage or generation capacity is distributed among small owners or installations and is pooled to provide a service as a 'virtual power plant' on a C2B or B2B level, this business activity is based on privately shared resources and represents a form of economic sharing similar to cloud computing [41]. On a C2C level, generation, storage or EV charging facilities can be shared with others on a commercial or not-for-profit basis, e.g., within energy cooperatives $[50,51]$. 


\subsubsection{Space}

As renewable energy technologies require a certain degree of space and the right location to work effectively, renting out space seems to be a viable sharing business model in the energy sector. Despite the contracts being on a more long-term basis compared to other models of shared space, like apartment sharing or garden sharing, several business models make use of this concept. Yeloha connected house owners who had roofs with potential for harnessing solar power to private investors who lacked the appropriate spot for PV installations [52]. The same concept might be possible for battery or heat storage and other decentralized technologies like wall boxes on a C2C or B2B level where space within basements, garages, etc. can be shared with others (\#1). At the same time, PV-leasing companies are already making use of this concept when installing capacities in households or companies and keeping some of the profit generated by this installation. While business models in this field rely on economic sharing of the used space, social and non-profit cooperation is also a possible form of sharing unused land potentials.

\subsubsection{Money}

The distribution of money for the purpose of facilitating the dissemination of renewable energy technologies and energy efficiency has already become a widespread business model. Crowd-financing, -investing or -funding enables C2C, C2B or B2B provision of money either based on a fixed credit rate or for free. Various platforms, like SunExchange, Mosaic, Econeers, or Bettervest, are active in this field and have become an important driver of financing sustainable energy systems [15]. On a B2B level, there exists a range of venture capital companies which allow businesses and investors to co-invest in renewable energy innovations and start-up companies. Another form of B2B lending of money can be seen with micro-funding initiatives [53]. Furthermore, microcredits can be granted on a B2C level to help the dissemination of renewable energy technologies especially in developing countries. Similarly, some companies have implemented "one-for-one schemes" (\#3) or "crowd distribution platforms" (\#1) in their business models to channel money towards beneficial causes in the region or clean energy sources in developing countries. Another form of non-profit sharing or exchange is facilitated by digital currencies based on blockchain technology, such as SolarCoin, which enables PV owners to create and exchange values in a solar community [42,54].

\subsubsection{Workforce (Time and Skills)}

On a B2C level, consultancy and installation of renewable energy technologies are services which are often offered to customers. Still, this is not related to sharing in the sense of a sharing economy. The explorative literature research on the sharing economy and energy management yielded no results which would fit into this category. Nevertheless, helping each other in local communities or in cooperatives might be a form a social sharing, which is not yet part of the discussion. Time banking concepts including experts with specific knowledge of energy technologies might be a form of organizing exchange of services in local energy communities of the future [50]. Furthermore, digital platforms can be used to organize volunteering events of companies together with their customers, e.g., to collect garbage from the riverbanks. These non-profit activities could strengthen customer connections based on shared values inherent to some sharing platforms (\#3). On a B2B level, skills can be shared within shared service competence centers or by offering or making use of white label products (\#2).

\subsubsection{Knowledge and Education}

Whereas the other categories discussed above have always focused on a good being shared in a distributional zero-sum game, sharing knowledge and sharing information are non-zero-sum games of communicational sharing. Knowledge in the field of energy could range from installation and maintenance of facilities, to energy trading, to efficiency in energy consumption, and optimal usage 
of electricity generation or storage facilities. Many B2C or B2B models which go beyond making information available and facilitating learning for participants are imaginable in this context and are probably already in place. Digital services, data transparency and information platforms may be used to help customers learn how to reduce and optimize their consumption behavior (\#2, \#3, \#4). These optimization services can be understood in terms of the reduction of energy consumption through energy efficiency and sufficiency but also in terms of adapting consumption patterns to the supply of electricity produced by local renewable power plants. Massive open online courses or learning platforms that enable communication within energy communities (\#5) might be other possible channels of knowledge dissemination, including C2C or G2C concepts. Smart home feedback mechanisms could help businesses retrieve knowledge about how to adapt their products and services to the customers. Finally, learning energy efficiency networks (LEEN) provide platforms to exchange knowledge and share experience on energy efficiency improvements between organizations of a specific region [55].

Furthermore, as people become prosumers and electrification via microgrids spreads in developing countries, online platforms for energy education become an important way to share knowledge about energy generation and usage [56,57]. As knowledge about installation, maintenance, and repair of energy technologies as well as about energy efficiency spreads, there might also be a new market for shared private workforce services.

\subsubsection{Data and Information}

Sharing information is an important component of many new services provided by energy utilities and new players in this sector $[41,58]$. Companies use smart technologies to aggregate information in a $\mathrm{C} 2 \mathrm{~B}$ manner, which allows them to coordinate and optimize the energy system in order to reduce costs [59]. At the same time, they can provide B2C or B2B transparency services and monitoring tools to their customers based on the gathered data, making the information widely available.

As the transaction costs for sharing information become negligible with further digitalization, these services may offer the backbone for many energy services of the future. Additionally, companies offering leasing and full-service of renewable generation facilities can profit from these synergies of having access to data along the energy value chain, reaching from generation, to usage, to storage [60].

At the same time, non-profit forms of sharing real-time data on energy generation are becoming available with crowdsourcing projects and blockchain technology. ElectriCChain, for example, gathers data on renewable energy generation and makes these available for "scientists, researchers and human progress" [61]. This might be a possible concept for social and non-profit sharing of information within community energy projects in the future.

\subsection{Characteristics of the Sharing Economy within the Energy Sector}

Clearly, not all business models mentioned in the previous section contain all defining characteristics of the sharing economy (compare Section 2.2). However, the purpose of this paper is not to include or exclude energy business models from the sharing economy, but rather to infuse concepts of the sharing economy in the energy sector to generate ideas for new business models. Correspondingly, this section will discuss what characteristics of the sharing economy are also applicable to the energy sector and what can be learned from them.

As electricity is a very complex good, most of its physical management and commercial trading is digital anyways. With the increasing shares of fluctuating and distributed renewable energy, there is also an increased requirement for coordination mechanisms which leverage on digital technologies (\#1, \#4). Accordingly, companies emerge that are mainly platform-based and focus on digital optimization of energy management and trading instead of owning the electricity production assets themselves (\#2). This development is very similar to what is happening in the sharing economy, where digital platforms coordinate transactions of companies and customers (B2C) or among customers (C2C).

Digital platforms for energy management and trading can also be used to connect small actors and consumers in the energy sector to enable $C 2 C$ interactions in terms of electricity, money, information, 
or knowledge. While some platforms offer direct purchase of electricity from certain renewable power plants and could be regarded as a more transparent form of green electricity (\#1, \#4), others connect prosumers and consumers of electricity on community platforms, integrating green electricity generation facilities and batteries to a digital network (\#2,\#4,\#5). Local implementation in microgrids, for example through district storages, neighborhood networks, or shared investments, often include increased C2C interaction and could be enhanced by digital platforms [11,62].

As the energy sector has traditionally been defined by large capital-intensive power plants, access instead of ownership has always been a basic principle of the energy system, where companies provide electricity as a service instead of the assets themselves (\#2). With the emergence of renewable energy technologies, the trend is moving towards ownership and temporal independence from the grid. At the same time, power purchase agreements or leasing schemes may help to overcome investment barriers by disseminating PV units and batteries that are still owned by the company but are in use at the household [15]. However, access to assets can also be shared among small scale actors, where digital technologies can be leveraged to enable sharing among prosumers and small businesses $[9,40]$.

Regarding 'making better use of idle capacities and underutilized resources', it is difficult to say that PV-plants have been made better use of if energy is distributed peer-to-peer because it would have been fed into the grid regardless and would not have been lost (\#4). Nevertheless, if energy is traded in a local network and incentives lead to better coordination of supply and demand, electricity networks might be used more efficiently to reduce transportation losses (\#2, \#5). Energy storage facilities or electric vehicles, on the other hand, might rarely be used to their full capacity by their individual owner, and sharing them with neighbors or in a district or community might be beneficial for all actors $(\# 1, \# 4)$. Because this underutilized asset aspect is not as strong in the energy sector as it might be in other sharing business models, significant cost advantages are difficult to achieve by sharing decentral energy technologies. Consequently, shared ecological and social values such as 'driving forward the energy transition' (\#2, \#3) and 'independence of big energy utilities' (\#4) might be more pronounced in sharing schemes within the energy sector. Having shared values might be especially important for local platforms with high interactions of actors, whereas sharing business models intending to scale globally would also need advantages in costs and convenience of their services (\#4). Uber and Airbnb, as globally successful examples of the sharing economy, compared to locally rooted tool libraries or community gardens, might serve as supportive illustrations for this assertion. Table 4 presents a summarizing overview of how characteristics of the sharing economy are relevant in the energy sector.

Table 4. Defining characteristics of the sharing economy and their applicability in the energy sector.

\begin{tabular}{|c|c|}
\hline Aspect & Application in the Energy Sector \\
\hline Platform-based & $\begin{array}{l}\text { Digital energy platform companies which do not own many assets } \\
\text { themselves, but instead offer services of coordination and optimization. }\end{array}$ \\
\hline Leverage on digital technologies & $\begin{array}{l}\text { Digital coordination mechanisms as the backbone of the energy } \\
\text { infrastructure, especially with increasingly fluctuating energy supply } \\
\text { and need for demand or storage management. }\end{array}$ \\
\hline $\begin{array}{l}\text { Consumer-to-consumer/ } \\
\text { peer-to-peer interaction }\end{array}$ & $\begin{array}{l}\text { Distributed decentral renewable energies, energy storage, and smart } \\
\text { management devices offer potential for increased C } 2 \mathrm{C} \text { interaction. } \\
\text { Local microgrids and digital platforms as spaces for increased C } \mathrm{C} \\
\text { exchange of energy, money, information, and knowledge. }\end{array}$ \\
\hline Access instead of ownership & $\begin{array}{l}\text { Traditional core principle of energy system. Now increasing ownership } \\
\text { of energy production, storage, and management devices in households } \\
\text { and small businesses. Potential for optimization by sharing among } \\
\text { decentral actors. }\end{array}$ \\
\hline $\begin{array}{l}\text { Under-utilized resources/Making } \\
\text { better use of idle capacities }\end{array}$ & $\begin{array}{l}\text { Not applicable for renewable energy generation facilities as these have } \\
\text { little to no idle capacities. Batteries and electric vehicles can be used } \\
\text { more efficiently if shared in districts or energy communities. }\end{array}$ \\
\hline Shared values/mission driven & $\begin{array}{l}\text { Important factor for sharing business models in the energy sector to } \\
\text { compensate for lack of cost advantages. Possibly even more pronounced } \\
\text { in local sharing activities. }\end{array}$ \\
\hline
\end{tabular}




\section{Discussion}

This paper does not claim to provide a comprehensive systematic overview of all new developments, activities, or organizations that are currently emerging in the energy sector and can be related to the sharing economy. The search for relevant articles was explorative and companies selected for the workshops may not represent all activities of the energy value chain. However, it provides a new perspective on many developments that are currently taking place in the energy system by analyzing overlaps and interfaces between the emerging sharing economy and the transitioning energy sector. Accordingly, the purpose of this paper's analysis was not to label activities in the energy sector as a sharing economy or not, but rather to see what characteristics of the sharing economy can be transferred to the energy sector and how sharing any type of resource might be beneficial in the context of a sustainable energy system.

In an economic sense (compare Section 2.1), power plants and their costs and benefits have always been shared among electricity consumers. However, it is only now that the increasing dissemination of distributed electricity generation units, battery storages, or electric vehicles offers new forms of decentral sharing of lumpy (i.e., come in certain capacities) and mid-grained (i.e., well distributed among households) goods within the energy system [21]. Correspondingly, this paper identified many possible business cases for economic or for-profit applications of sharing resources. Still, a considerable number of activities have also been found which offer potential for non-profit or social sharing schemes, possibly locally, specifically in the realm of sharing knowledge and information.

For practitioners, the presented systematization of business models (Figure 2) might be a good overview of existent sharing activities in the energy sector for building or extending their own business models. While this study deliberately used a broad and undefined understanding of the term 'business model' to account for a wide range of activities within the energy sector and the sharing economy, a more detailed analysis of the mentioned business models or activities might provide additional insights into the topic. The deposition of sharing business models or companies within the energy sector into their different components and the separated analysis of value creation, value proposition and value capture seems to be fruitful grounds for further research on this topic [15,63,64].

Furthermore, based on the overview in Figure 2, platform-based organizations might create synergies by enabling platform users to share different kinds of resources. Accordingly, a digital platform could be used to trade energy, organize shared investments, provide information through transparency and optimization services on energy consumption and production, or facilitate the dissemination of knowledge. In this context, two major developments are partly in contradiction of one another. On the one hand, there is the 'democratization' of energy with raising shares of decentralized generation and storage technologies empowering people to be prosumers and P2P energy traders [12,56]. In this context, McIntosh [65] recommends that grid operators create business models which avoid the threat of prosumers going off-grid. On the other hand, many new business models rely on B2C 'access instead of ownership' models to overcome investment barriers and facilitate energy management. In this case, the ownership of the new technological devices is bundled in the hands of companies who manage those centrally and in the form of virtual power plants. Accordingly, utilities can become B2C asset hubs by providing PSS services, they can become P2P platforms aggregating managing information and energy flows, or they can do both. This might create tendencies towards aggregation of power, information and know-how across the energy supply chain in the hands of new actors [60]. However, when electricity generation costs and profits that can be generated for intermediaries decrease, social sharing models might become a widely spread form of managing the energy system [21,27].

While researchers are already engaging in designing new market designs for prosumer-based energy systems and sharing energy within microgrids [11,12,59], similar aspects between the sharing economy and the changing energy system might provide more potential for research interfaces. Researched mechanisms of trust establishment, consumer engagement, or community management from the sharing economy might be transferable to organizations managing P2P energy trading 
platforms, energy communities, or local microgrids. Furthermore, coordination mechanisms and algorithms for connecting prosumers as well as the necessary recruitment of critical masses for digital platforms to work successfully could provide further overlaps in research interests. However, at this point, it also has to be acknowledged that with respect to sharing assets, the energy market represents a unique case for its physical attributes and restrictions within the electricity grid, with trading being mainly virtual $(\# 4, \# 5)$. In this context, rural areas in developing countries where electrification and grid infrastructures are still scarce might provide particularly interesting cases for shared energy facilities.

\section{Conclusions}

The purpose of this paper was to investigate the interfaces and overlaps between new business models of a sharing economy and an energy system with increasing shares of decentral renewable energies. For this purpose, existent scientific and grey literature on this topic as well as insights from empirical company workshops were analyzed along a conceptual typology of sharing activities [32] and defining characteristics of the sharing economy [22,28,31]. It was found that both fields have significant overlaps in their characteristics and that a broad range of business models within the energy system can be based on sharing resources. The presented findings offer significant potential for organizations to advance and adapt their business models in an energy system transitioning towards more decentralized and renewable energy technologies. Furthermore, researchers and practitioners can make use of observations in both fields to transfer knowledge on platform organizations, digital coordination mechanisms, or community management and consumer interactions to their field of action. In summary, results of this study suggest that sharing resources along various dimensions can play an important role in contributing to a more resource- and cost-efficient energy system.

Funding: This research was funded by the Friedrich and Elisabeth Boysen Foundation (BOY 109) and TU Dresden.

Acknowledgments: The author is very thankful for the vivid discussions and feedback provided within the regular colloquia of the Boysen TU Dresden Research Training Group and within the research seminars at the Faculty of Business of the TU Dresden. Furthermore, the author expresses his sincere thanks for the valuable comments on earlier versions of this paper received from participants of the Annual Meeting of the Academy of Management in Atlanta, 2017, the 5th International Workshop on the Sharing Economy in Mannheim, 2018, and from the anonymous reviewers of the journal review process.

Conflicts of Interest: The author declares no conflict of interest. The funders had no role in the design of the study, in the collection, analyses, or interpretation of data, in the writing of the manuscript, or in the decision to publish the results.

\section{References}

1. Geissinger, A.; Laurell, C.; Sandström, C. Digital Disruption beyond Uber and Airbnb-Tracking the long tail of the sharing economy. Technol. Forecast. Soc. Chang. 2018. [CrossRef]

2. Botsman, R.; Rogers, R. What's Mine Is Yours: The Rise of Collaborative Consumption; HarperCollins: New York, NY, USA, 2010.

3. Cohen, B.; Muñoz, P. Sharing cities and sustainable consumption and production: Towards an integrated framework. J. Clean. Prod. 2015, 134, 87-97. [CrossRef]

4. Briggs, L. NEWS: Does Energy Have a Place in the Sharing Economy? Available online: http://blog.aee.net/ news-does-energy-have-a-place-in-the-sharing-economy (accessed on 3 January 2017).

5. Johnston, J. What Is the Sharing Economy-And What Does It Mean for the Energy Industry? I Nominet Trust. Available online: http:/ / www.nominettrust.org.uk/what-we-support/blogs/what-sharing-economy-andwhat-does-it-mean-energy-industry (accessed on 5 January 2017).

6. Müller, S.C.; Welpe, I.M. Sharing electricity storage at the community level: An empirical analysis of potential business models and barriers. Energy Policy 2018, 118, 492-503. [CrossRef]

7. Liu, J.; Zhang, N.; Kang, C.; Kirschen, D.; Xia, Q. Cloud energy storage for residential and small commercial consumers: A business case study. Appl. Energy 2017, 188, 226-236. [CrossRef]

8. Lombardi, P.; Schwabe, F. Sharing economy as a new business model for energy storage systems. Appl. Energy 2017, 188, 485-496. [CrossRef] 
9. Qi, W.; Shen, B.; Zhang, H.; Shen, Z.-J.M. Sharing demand-side energy resources-A conceptual design. Energy 2017, 135, 455-465. [CrossRef]

10. Alvaro-Hermana, R.; Fraile-Ardanuy, J.; Zufiria, P.J.; Knapen, L.; Janssens, D. Peer to Peer Energy Trading with Electric Vehicles. IEEE Intell. Transp. Syst. Mag. 2016, 8, 33-44. [CrossRef]

11. Mengelkamp, E.; Gärttner, J.; Rock, K.; Kessler, S.; Orsini, L.; Weinhardt, C. Designing microgrid energy markets: A case study: The Brooklyn Microgrid. Appl. Energy 2018, 210, 870-880. [CrossRef]

12. Parag, Y.; Sovacool, B.K. Electricity market design for the prosumer era. Nat. Energy 2016, 1, 16032. [CrossRef]

13. Jenny, A.; Fuentes, F.H.; Mosler, H.-J. Psychological Factors Determining Individual Compliance with Rules for Common Pool Resource Management: The Case of a Cuban Community Sharing a Solar Energy System. Hum. Ecol. 2006, 35, 239-250. [CrossRef]

14. Rathnayaka, A.J.D.; Potdar, V.M.; Dillon, T.; Kuruppu, S. Framework to manage multiple goals in community-based energy sharing network in smart grid. Int. J. Electr. Power Energy Syst. 2015, 73, 615-624. [CrossRef]

15. Wainstein, M.E.; Bumpus, A.G. Business models as drivers of the low carbon power system transition: A multi-level perspective. J. Clean. Prod. 2016, 126, 572-585. [CrossRef]

16. Belk, R. Sharing. J. Consum. Res. 2010, 36, 715-734. [CrossRef]

17. Tomalty, R. Ours Is Better Than Yours. Altern. J. 2014, 40, 18-22.

18. Belk, R. Sharing Versus Pseudo-Sharing in Web 2.0. Anthropologist 2014, 18, 7-23. [CrossRef]

19. Eckhardt, G.M.; Bardhi, F. The Sharing Economy Isn't About Sharing at All. Harv. Bus. Rev. 2015. Available online: https:/ /hbr.org/2015/01/the-sharing-economy-isnt-about-sharing-at-all (accessed on 29 April 2016).

20. Belk, R. Why Not Share Rather Than Own? Ann. Am. Acad. Pol. Soc. Sci. 2007, 611, 126-140. [CrossRef]

21. Benkler, Y. Sharing Nicely: On Shareable Goods and the Emergence of Sharing as a Modality of Economic Production. Yale Law J. 2004, 114, 273-358. [CrossRef]

22. Frenken, K.; Schor, J. Putting the sharing economy into perspective. Environ. Innov. Soc. Transit. 2017, 23, 3-10. [CrossRef]

23. John, N.A. The Social Logics of Sharing. Commun. Rev. 2013, 16, 113-131. [CrossRef]

24. John, N.A. Sharing and Web 2.0: The emergence of a keyword. New Media Soc. 2013, 15, 167-182. [CrossRef]

25. Wittel, A. Qualities of sharing and their transformations in the digital age. Int. Rev. Inf. Ethics 2011, 15, 3-8.

26. Schor, J.B.; Fitzmaurice, C.J. Collaborating and connecting: The emergence of the sharing economy. In Handbook of Research on Sustainable Consumption; Reisch, L., Thogerson, J., Eds.; Edward Elgar: Cheltenham, UK, 2015; pp. 410-425.

27. Rifkin, J. The Zero Marginal Cost Society: The Internet of Things, the Collaborative Commons, and the Eclipse of Capitalism; Palgrave Macmillan: New York, NY, USA, 2014; ISBN 978-1-137-43776-1.

28. Acquier, A.; Daudigeos, T.; Pinkse, J. Promises and paradoxes of the sharing economy: An organizing framework. Technol. Forecast. Soc. Chang. 2017, 125, 1-10. [CrossRef]

29. Codagnone, C.; Biagi, F.; Abadie, F. The Passions and the Interests: Unpacking the "Sharing Economy"; Social Science Research Network: Rochester, NY, USA, 2016.

30. Codagnone, C.; Martens, B. Scoping the Sharing Economy: Origins, Definitions, Impact and Regulatory Issues; Social Science Research Network: Rochester, NY, USA, 2016.

31. Munoz, P.; Cohen, B. Mapping out the Sharing Economy: A Configurational Approach to Sharing Business Modeling. Technol. Forecast. Soc. Chang. 2017, 125, 21-37. [CrossRef]

32. Plewnia, F.; Guenther, E. Mapping the sharing economy for sustainability research. Manag. Decis. 2018, 56, 570-583. [CrossRef]

33. Botsman, R. Defining the Sharing Economy: What Is Collaborative Consumption-And What Isn't? Available online: https:/ / www.fastcompany.com/3046119/defining-the-sharing-economy-what-iscollaborative-consumption-and-what-isnt (accessed on 8 January 2019).

34. Engelken, M. Studies on Energy Self-Sufficiency in Germany and Business Models for Renewable Energies; TU München: München, Germany, 2017.

35. Fuchs, G.; Hinderer, N. Towards a low carbon future: A phenomenology of local electricity experiments in Germany. J. Clean. Prod. 2016, 128, 97-104. [CrossRef]

36. Richter, M. Business model innovation for sustainable energy: German utilities and renewable energy. Energy Policy 2013, 62, 1226-1237. [CrossRef] 
37. Belk, R. You are what you can access: Sharing and collaborative consumption online. J. Bus. Res. 2014, 67, 1595-1600. [CrossRef]

38. Haase, P.D.M.; Pick, D.D. Value Creation in Sharing Networks. In Interaktive Wertschöpfung durch Dienstleistungen; Bruhn, M., Hadwich, K., Eds.; Springer: Wiesbaden, Germany, 2015; pp. 439-468, ISBN 978-3-658-08517-9.

39. Stokes, K.; Clarence, E.; Anderson, L.; Rinne, A. Making Sense of the UK Collaborative Economy; Nesta: London, UK, 2014.

40. Liu, N.; Guo, B.; Liu, Z.; Wang, Y.; Liu, N.; Guo, B.; Liu, Z.; Wang, Y. Distributed Energy Sharing for PVT-HP Prosumers in Community Energy Internet: A Consensus Approach. Energies 2018, 11, 1891. [CrossRef]

41. Loock, M.; Reuter, E.; von der Tann, K. Ideal-Type Business Models for Local Smart Grids; Local Electricity Retail Markets for Prosumer Smart Grid pOWER Services (EMPOWER); European Union's Horizon 2020 Research and Innovation Programme; SmartIO: Halden, Norway, 2016.

42. Deign, J. Siemens Joins the Growing Blockchain Bandwagon for Peer-To-Peer Energy Sales. Available online: https://www.greentechmedia.com/articles/read/siemens-joins-growing-blockchainbandwagon (accessed on 3 January 2017).

43. Prisco, G. Blockchain Technology Could Enable Next-Generation, Peer-To-Peer Energy Microgrids. Available online: https://bitcoinmagazine.com/articles/blockchain-technology-could-enable-nextgeneration-peer-to-peer-energy-microgrids-1461596932 (accessed on 3 January 2017).

44. Wang, J.; Wang, Q.; Zhou, N.; Chi, Y.; Wang, J.; Wang, Q.; Zhou, N.; Chi, Y. A Novel Electricity Transaction Mode of Microgrids Based on Blockchain and Continuous Double Auction. Energies 2017, 10, 1971. [CrossRef]

45. Siemens-Mitarbeiter Können Elektrofahrzeuge Kostenlos Laden. Available online: http://www.siemens. $\mathrm{com} /$ press/de/pressemitteilungen/?press=/de/pressemitteilungen/2016/corporate/pr2016120125code. htm\&content[]=Corp (accessed on 10 January 2017).

46. Grant, G.B.; Seager, T.P.; Massard, G.; Nies, L. Information and Communication Technology for Industrial Symbiosis. J. Ind. Ecol. 2010, 14, 740-753. [CrossRef]

47. Raabe, B.; Low, J.S.C.; Juraschek, M.; Herrmann, C.; Tjandra, T.B.; Ng, Y.T.; Kurle, D.; Cerdas, F.; Lueckenga, J.; Yeo, Z.; et al. Collaboration Platform for Enabling Industrial Symbiosis: Application of the By-product Exchange Network Model. Procedia CIRP 2017, 61, 263-268. [CrossRef]

48. Ahmadi, L.; Young, S.B.; Fowler, M.; Fraser, R.A.; Achachlouei, M.A. A cascaded life cycle: Reuse of electric vehicle lithium-ion battery packs in energy storage systems. Int. J. Life Cycle Assess. 2017, 22, 111-124. [CrossRef]

49. Casals, L.C.; García, B.A.; Aguesse, F.; Iturrondobeitia, A. Second life of electric vehicle batteries: Relation between materials degradation and environmental impact. Int. J. Life Cycle Assess. 2017, 22, 82-93. [CrossRef]

50. Heinonen, S.; Karjalainen, J.; Ruotsalainen, J. Radical Transformation in a Distributed Society-Neo-Carbon Energy Scenarios 2050; NEO-CARBON ENERGY WP1 WO RKING PAPER 1/2016; Finland Futures Research Centre: Turku, Finland, 2016.

51. Matzner, M.; Chasin, F.; Hoffen, M.V.; Plenter, F.; Becker, J. Designing a Peer-to-Peer Sharing Service as Fuel for the Development of the Electric Vehicle Charging Infrastructure. In Proceedings of the 2016 49th Hawaii International Conference on System Sciences (HICSS), Koloa, HI, USA, 5-8 January 2016; pp. 1587-1595.

52. Owyang, J. How the Collaborative Economy Is Impacting the Energy Sector. Available online: http:/ / www.web-strategist.com/blog/2015/04/23/how-the-collaborative-economy-is-impacting-theenergy-sector / (accessed on 3 January 2017).

53. O'Callaghan, Q. Shared Interest: A Unique Microlending Plan in Philly. Philadelphia Citizen. 2017. Available online: https:/ / thephiladelphiacitizen.org/shared-interest-microlending/ (accessed on 10 January 2019).

54. Johnson, L.; Isam, A.; Gogerty, N.; Zitoli, J. Connecting the Blockchain to the Sun to Save the Planet; Social Science Research Network: Rochester, NY, USA, 2015.

55. Köwener, D.; Nabitz, L.; Mielicke, U.; Idrissova, F. Learning energy efficiency networks for companies-Saving potentials, realization and dissemination. In Proceedings of the ECEEE Industrial Summer Study Proceedings, Arnheim, The Netherlands, 2-5 June 2014.

56. Gstrein, M.; Teufel, S. Crowd Energy Management: New Paradigm for Electricity Market. J. Electron. Sci. Technol. 2015, 13, 195-205. 
57. Parag, P. Beyond energy efficiency: A 'prosumer market' as an integrated platform for consumer engagement with the energy system. In Proceedings of the ECEEE 2015 Summer Study on Energy Efficiency, Hyères, France, 1-6 June 2015; pp. 15-23.

58. Dauer, D.; vom Scheidt, F.; Weinhardt, C. Towards Smart Distribution Grids: A Structured Market Engineering Review. In 6th Karlsruhe Service Summit, Karlsruhe, Germany; Grin Publishing: München, Germany, 2016.

59. Zhu, T.; Huang, Z.; Sharma, A.; Su, J.; Irwin, D.; Mishra, A.; Menasche, D.; Shenoy, P. Sharing Renewable Energy in Smart Microgrids. In Proceedings of the ACM/IEEE 4th International Conference on Cyber-Physical Systems, Philadelphia, PA, USA, 8-11 April 2013; pp. 219-228.

60. Gauntlett, D. Tesla-SolarCity Merger Talks Are Only Tip of the Energy Cloud. Available online: http:/ / www.renewableenergyworld.com/articles/2016/08/tesla-solarcity-merger-talks-are-only-tip-ofthe-energy-cloud.html (accessed on 3 January 2017).

61. ElectriCChain ElectriCChain. Available online: http://www.electricchain.org/our-projects/project-13/ (accessed on 5 January 2017).

62. Giotitsas, C.; Pazaitis, A.; Kostakis, V. A peer-to-peer approach to energy production. Technol. Soc. 2015, 42, 28-38. [CrossRef]

63. Bolton, R.; Hannon, M. Governing sustainability transitions through business model innovation: Towards a systems understanding. Res. Policy 2016, 45, 1731-1742. [CrossRef]

64. Engelken, M.; Römer, B.; Drescher, M.; Welpe, I.M.; Picot, A. Comparing drivers, barriers, and opportunities of business models for renewable energies: A review. Renew. Sustain. Energy Rev. 2016, 60, 795-809. [CrossRef]

65. McIntosh, B. Distributed Solar with Storage and Disconnection? In Proceedings of the Asia-Pacific Solar Research Conference, Sydney, Australia, 8-10 December 2014.

(C) 2019 by the author. Licensee MDPI, Basel, Switzerland. This article is an open access article distributed under the terms and conditions of the Creative Commons Attribution (CC BY) license (http:/ / creativecommons.org/licenses/by/4.0/). 